\title{
New Records of Metleucauge davidi (Araneae: Tetragnathidae) from Taiwan with the First Description of the Male.
}

\author{
Akio TANIKAWA ${ }^{1)}$ and Yung-Hau $\mathrm{CHANG}^{2)}$ \\ 谷川明男 ${ }^{1)}$ ・張 永浩 ${ }^{2}$ : Metleucauge davidi (クモ目： \\ アシナガグモ科）の台湾での新記録および雄の初記載
}

\begin{abstract}
Metleucauge davidi (SCHENKEL, 1963) is newly recorded from Taiwan. The male of the species is described for the first time.
\end{abstract}

Metleucauge davidi (SCHENKEL, 1963) was described under the genus Meta based on the female holotype from Shensi, China. After LEVI (1980) described the genus Metleucauge, CHENG and ZHANG (1991) transferred the species to the genus Metleucauge and recorded it from Zhejiang, China. The male of the species has not been described up to the present. Recently, Yung-Hau CHANG, collected two specimens of a spider species probably belonging to Metleucauge at Mt. Chilai-shan, Hualien Hsien, Taiwan. After careful examination, we identified it as Metleucauge davidi. In this paper, the spider is newly recorded from Taiwan, and the male of the species is described for the first time.

The Taiwanese specimens examined in this paper are deposited in the collection of the Department of Zoology, National Science Museum, Tokyo (NSMT).

We wish to express our hearty thanks to Dr. Hirotsugu ONO, Department of Zoology, National Science Museum, Tokyo, for revising the manuscript of this paper. Our hearty thanks are also due to Dr. Christine Rollard, Laboratoire de Zoologie, Museum National d'Histoire Naturelle, Paris (MNHN), for loaning invaluable specimen.

Metleucauge davidi (SCHENKEL, 1963)

(Figs. 1-6)

Meta davidi SChenkel, 1963, p. 130. (우 Holotype from Shensi, China, Preserved in MNHN, examined.)

Metleucauge davidi: CHEN \& ZHANG, 1991, p. 103.

Specimens examined. Holotype: 우, Hantschong fu, Süd Schensi, China, 1873 (MNHN B1064).

1) Shichirigahama Senior High School, 2-3-1, Shichirigahama-higashi, Kamakura-shi, Kanagawa, 248 Japan

神奈川県立七里ガ浜高等学校７248 神奈川県鎌倉市七里ガ浜東 2-3-1

2) Institute of Life Science, Department of Biology, National Sun Yat-Sen University, Kaohsiung, 80424 Taiwan, R. O. C.

国立中山大学生命科学研究所 中華民国台湾省高雄市西子湾蓮海路

Accepted November 11, 1997 

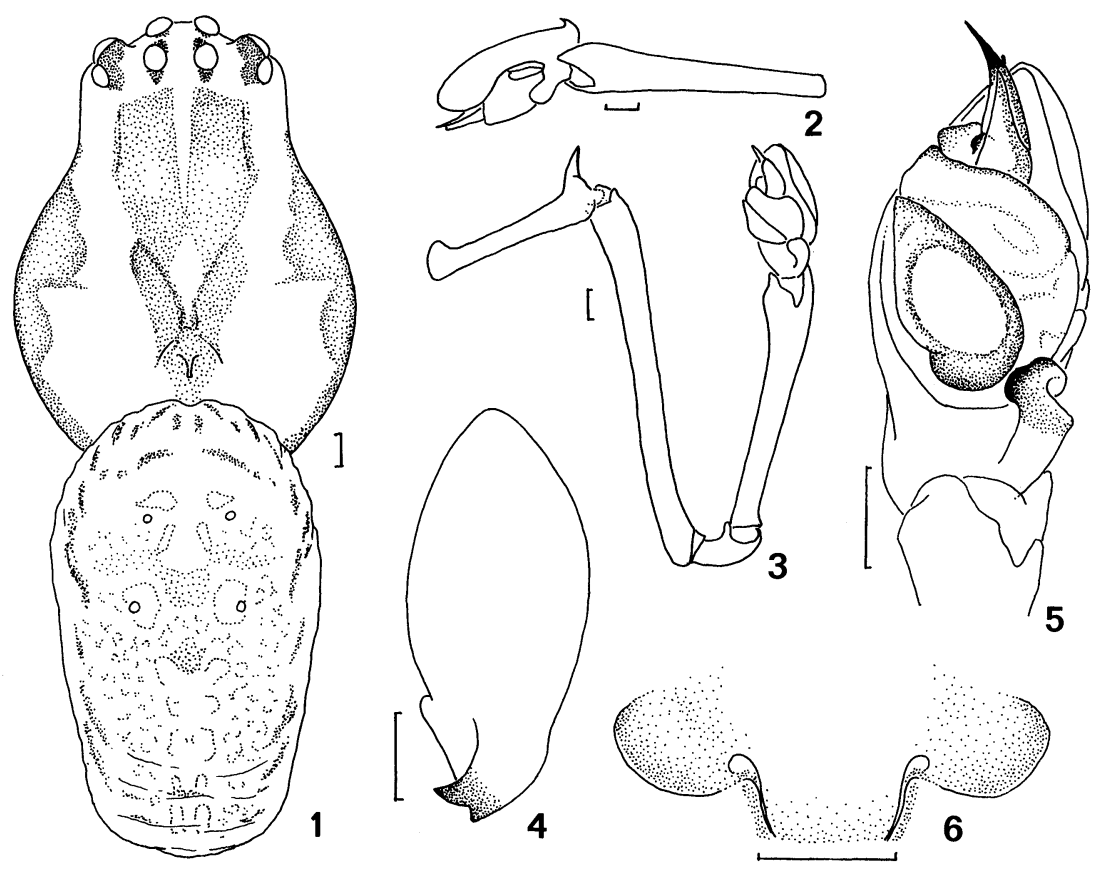

Figs. 1-6. Metleucauge davidi (SCHENKEL, 1963) (Male: NSMT-Ar 3383; female: NSMT-Ar 3384.) - 1. Male carapace and abdomen, dorsal view. 2. Tarsus and tibia of male palp, retrolateral view. 3. Male palp, general view. 4. Cymbium of male palp, dorsal view. 5. Tarsus of male palp, ventral view. 6. Epigynum, ventral view. (Scales: $0.25 \mathrm{~mm}$.)

Table 1. Measurement of leg segments of Metleucauge davidi (SCHENKEL, 1963) (in mm;

\begin{tabular}{ccccccc}
\multicolumn{7}{c}{$\sigma^{\top} /$ o $)}$. \\
\hline Leg & Tarsus & Metatarsus & Tibia & Patella & Femur & Total \\
\hline I & $2.60 / 2.42$ & $9.00 / 7.25$ & $7.50 / 6.25$ & $2.00 / 1.92$ & $7.50 / 6.54$ & $28.60 / 24.38$ \\
II & $1.70 / 1.67$ & $5.80 / 4.83$ & $4.95 / 4.21$ & $1.65 / 1.67$ & $5.55 / 4.92$ & $19.65 / 17.30$ \\
III & $1.05 / 1.00$ & $2.80 / 2.50$ & $2.30 / 2.17$ & $1.00 / 1.08$ & $3.35 / 2.92$ & $10.50 / 9.67$ \\
IV & $1.20 / 1.17$ & $4.60 / 3.96$ & $4.10 / 3.67$ & $1.10 / 1.25$ & $4.80 / 4.50$ & $15.80 / 14.55$ \\
\hline
\end{tabular}

Specimens from Taiwan. 1 구 1 우, Mt. Chilai-shan, 3,000 m alt, Taroko National Park, Hualien Hsien, Taiwan, 27-IX-1996, Y.-H. CHANG leg. (NSMT-Ar 3383-3384).

Description. Measurement (in $\mathrm{mm}$ ). Total length, o7 7.38, 우 8.33; carapace length or 3.64, 우 3.68; width or 2.64, 우 2.88; abdomen length o 3.60 , 우 4.50; width o7 2.24, 우 3.00. Length of legs of male and female from Taiwan (NSMT-Ar 3383-3384) as shown in Table 1.

Male: Carapace length/width 1.38, median ocular area length/width 0.91 , anterior width/posterior width 0.89 . Chelicera with 3 promarginal and 4 retromarginal teeth. Labium length/width 0.82 , sternum length/width 1.17 . Length of leg I/length of carapace 7.86. Male palp (Figs. 2-5): tibia two times as long as cymbium (tibia/ cymbium 2.00), femur about three times as long as cymbium (femur/cymbium 2.88), 
femur about one and a half times as long as tibia (femur/tibia 1.48). Abdomen length/ width 1.61 .

Female: Carapace length/width 1.28; median ocular area length/width 0.88 , anterior width/posterior width 0.83 . Chelicera with 3 promarginal and 4 retromarginal teeth. Labium length/width 0.71, sternum length/width 1.11. Abdomen length/width 1.50. Epigynum with a gently sloping bulge in the middle (Fig. 6).

Coloration and markings in alcohol. Male and female: Carapace light brown, marginated with dark brown, with $\mathrm{V}$-shaped dark brown marking between eye area and median fovea (Fig. 1). Abdomen dusky white with dark colored markings.

Range. China (Shensi and Zhejiang), Taiwan.

Remarks. The general appearance of Metleucauge davidi resembles M. chikunii TANIKAWA, 1992, and M. eldorado LEVI, 1980. The epigynum of $M$. davidi closely resembles that of $M$. eldorado, and quite different from that of $M$. chikunii (cf. Fig. 6; LEVI, 1980, fig. 137; TANIKAWA, 1992, fig. 21.). M. chikunii is occurring in Japan and Taiwan, while $M$. eldorado is occurring in U.S.A. Judging from the shape of the epigynum, $M$. davidi seems to be more closely related to American M. eldorado rather than Asian M. chikunii. $M$. davidi can be separated from $M$. eldorado by the shape of the male palp (cf. Figs. 2-5; LEVI, 1980, figs. 145-150).

\section{摘要}

Metleucauge davidi (SCHENKEL，1963）を台湾から初めて記録した。また，本種の雄 を初めて記載した。

\section{References}

CHEN, Z. \& Z. ZHANG, 1991. Araneida. In: Fauna of Zhejiang. pp. 1-356. Zhejiang Science and Technology Publishing House, Zhejiang.

LEVI, H. W., 1980. The orb-weaver genus Mecynogea, the subfamily Metinae and the genera Pacygnatha, Glenognatha and Azillia of the subfamily Tetragnathinae North of Mexico (Araneae: Araneidae). Bull. Mus. comp. Zool., 149:1-75.

SChEnKel, E., 1963. Ostasiatische spinnen aus dem Muséum d'Histoire Naturelle de Paris. Mém. Mus. natn. Hist. nat., Paris, (A), 24:1-288.

TanikawA, A., 1992. A revision of the Japanese spiders of the genus Metleucauge LEVI, 1980 (Araneae: Tetragnathidae). Acta arachnol., 41:161-175. 